\title{
Long-term effects of environmentally relevant concentrations of silver nanoparticles on major soil bacterial phyla of a loamy soil
}

\author{
Anna-Lena Grün and Christoph Emmerling * (1)
}

\begin{abstract}
Background: The growing production and use of engineered AgNP in industry and private households make increasing concentrations of AgNP in the environment unavoidable. Although we already know the harmful effects of AgNP on pivotal bacterial driven soil functions, information about the impact of silver nanoparticles (AgNP) on the soil bacterial community structure is rare. Hence, the aim of this study was to reveal the long-term effects of AgNP on major soil bacterial phyla in a loamy soil. The study was conducted as a laboratory incubation experiment over a period of 1 year using a loamy soil and AgNP concentrations ranging from 0.01 to $1 \mathrm{mg} \mathrm{AgNP/kg}$ soil. Effects were quantified using the taxon-specific $16 \mathrm{~S}$ rRNA qPCR.

Results: The short-term exposure of AgNP at environmentally relevant concentration of $0.01 \mathrm{mg} \mathrm{AgNP} / \mathrm{kg}$ caused significant positive effects on Acidobacteria (44.0\%), Actinobacteria (21.1\%) and Bacteroidetes (14.6\%), whereas betaProteobacteria population was minimized by $14.2 \%$ relative to the control $(p \leq 0.05)$. After 1 year of exposure to $0.01 \mathrm{mg} \mathrm{AgNP} / \mathrm{kg}$ diminished Acidobacteria $(p=0.007)$, Bacteroidetes $(p=0.005)$ and beta-Proteobacteria $(p=0.000)$ by 14.5, 10.1 and 13.9\%, respectively. Actino- and alpha-Proteobacteria were statistically unaffected by AgNP treatments after 1-year exposure. Furthermore, a statistically significant regression and correlation analysis between silver toxicity and exposure time confirmed loamy soils as a sink for silver nanoparticles and their concomitant silver ions.

Conclusions: Even very low concentrations of AgNP may cause disadvantages for the autotrophic ammonia oxidation (nitrification), the organic carbon transformation and the chitin degradation in soils by exerting harmful effects on the liable bacterial phyla.
\end{abstract}

Keywords: Silver Nanoparticles, Soil, Bacteria phyla, Acidobacteria, Actinobacteria, Bacteroidetes, alpha-Proteobacteria, beta-Proteobacteria

\section{Background}

The increasing production and use of engineered silver nanoparticles (AgNP) in households, industry and agriculture [1-3] are leading to increased concentrations of AgNP in the environment. In Europe, Sun et al. [4] modelled a production of 32.4 tons year ${ }^{-1}$ nanosilver and predicted an annual increase of AgNP in the range of $1.2 \mathrm{ng} /$ (kg year) to $2.3 \mathrm{ng} /(\mathrm{kg}$ year) for sediments and soils [4].

\footnotetext{
*Correspondence: emmerling@uni-trier.de

Department of Soil Science, Faculty of Regional and Environmental Science, University of Trier, Campus II, Behringstraße 21, 54296 Trier, Germany
}

Soil is expected as the major sink for AgNPs released into the environment [5]. Considering the antimicrobial effects of AgNP and their concomitant $\mathrm{Ag}^{+}$ions $[1,6$, 7], an ecological risk assessment of AgNP is needed, but it requires understanding the long-term effects of environmentally relevant concentrations of AgNP on the soil microbiome.

Quite recently, we documented significant negative effects on soil microbial biomass and bacterial ammonia oxidizers after 1-year exposure to $0.01 \mathrm{mg} \mathrm{AgNP} / \mathrm{kg}$ in a loamy soil [8]. The tested AgNP concentrations of 0.01$1.00 \mathrm{mg} \mathrm{AgNP} / \mathrm{kg}$ were shown to significantly decrease the leucine aminopeptidase activity as well as the 
abundance of nitrogen fixing microorganism in our longterm investigation [8]. In addition, Hänsch and Emmerling [2] observed also a decrease in soil microbial biomass with increasing AgNP concentrations (0.0032-0.320 mg AgNP/ $/ \mathrm{kg}$ ) in a sandy loam after 4 months. These studies clearly demonstrate the significance of AgNP for soil functions like the organic matter transformation and the cycling of energy and nutrients $[9,10]$.

However, information about the impact of AgNP on the soil bacterial community structure is rare, although microbial communities are important and sensitive targets for determining the environmental hazards of AgNP [11]. Bacteria are the main performer of functional processes, which are integral for maintenance of healthy soil environments [12]. Some studies already documented the toxicity of AgNP to specific soil bacteria like Pseudomonas putida [13, 14] and P. chlororaphis [15] in single species studies. Moreover, analyses of the soil bacterial community composition after AgNP exposure were focused on phylum level. These revealed an AgNP intolerance by Acido- and Actinobacteria, whereas Proteobacteria and Bacteroidetes seemed to be unaffected or promoted by silver applications [16-19]. This might lead to devastating effects on acidobacterial driven organic carbon transformation [20] as well as on actinobacterial recycling of refractory biomaterials by decomposition and humus formation in soils [21]. As mentioned above, Shah et al. [22] observed not only a shift in the bacterial community structure after addition of $0.0625 \mathrm{mg}$ AgNP/ $\mathrm{kg}$ soil, but also a shift dependent on exposure time. The species richness sharply declined by prolonged incubation, which might be a response to the changing chemical state of silver in the soil [22].

In virtue of the numerous AgNP on the market, evaluating their potential ecotoxicological effects remains an essential challenge. The size, shape, surface-coating agent, charge and stability of AgNP are only some of the properties that can differ [1], and the characteristics of soils are also very distinct. Several studies indicated that the physicochemical characteristics of soils, like clay content, $\mathrm{pH}$ value and organic matter content correlated to various effects by AgNP and thus toxicity [23, 24]. Considering the significance of soil microbial communities for soil ecosystem function, such as plant growth carbon sequestration and degradation of xenobiotics [25] and the predicted increase of nanoparticle release into the environment, the aim of this study was to reveal the adverse long-term effects of AgNP on soil bacterial community structure. The study was conducted with an incubation period of 1 year using a loamy soil and AgNP concentrations in an environmentally relevant range (0.01-1.00 mg AgNP/kg soil). We measured the effects on a set of soil dominating bacterial phlya Acidobacteria,
Actinobacteria, Bacteroidetes, alpha-Proteobacteria and beta-Proteobacteria by quantified marker genes using quantitative real-time PCR (qPCR).

\section{Methods \\ Experimental setup}

To assess the effects of silver nanoparticles (AgNP) on soil microbes, $20 \mathrm{~kg}$ of a loamy soil was sampled from the Ap horizon (0-30 cm depth) of an arable field cultivated with winter wheat in May 2013. The site is located at Helenenberg, NW of Trier, Germany (DD $49.8526^{\circ} \mathrm{N}$, $6.5417^{\circ} \mathrm{E}$ ). The soil can be characterized as a deeply developed haplic Stagno-Luvisol derived from Pleistocene eolian loess covering Middle Triassic limestone. The soil texture had a clay content of $17 \%-30 \%$. The soil properties were previously described by Grün et al. [8] After sampling, the soil was thoroughly sieved to $<2 \mathrm{~mm}$ and stored at $6{ }^{\circ} \mathrm{C}$ until further use.

Silver nanoparticles (AgNP), in the form of the certified reference material BAM-N001 (AgPure for analytical measurements [26] were purchased from Ras Materials (Regensburg, Germany). The AgPure stock solution $(100 \mu \mathrm{g} / \mathrm{ml})$ was homogenized by shaking by hand for 3 min according to manufacturer's instructions and then diluted stepwise using ultrapure water. Silver nitrate $\left(\mathrm{AgNO}_{3}\right)$ was used as a positive control. Silver concentrations in the $\mathrm{AgNO}_{3}$ controls were the same as those in the AgNP treatments.

Before applying the test materials, the soil was moistened to a water content of $15.3 \%$, which was equivalent to $40 \% \mathrm{WHC}_{\max }$ and incubated at $18{ }^{\circ} \mathrm{C}$ for 7 days. The application of the test materials was performed in petri dishes, each filled with soil equivalent to $25 \mathrm{~g}$ dry weight. Then, $1 \mathrm{~mL}$ AgPure or $\mathrm{AgNO}_{3}$ solutions, at different concentrations, was added in small drops onto the soil surface to obtain final concentrations of 10,100 and $1000 \mu \mathrm{g} / \mathrm{kg}$ dry weight. Negative controls only received an application of ultrapure water. For each concentration, day and replicate, separate soil dishes were used. Subsequently, soils were extensively mixed by stirring with a spoon, and then they were transferred to plastic containers (Centrifuge Tubes, $50 \mathrm{~mL}$, VWR, Darmstadt, Germany) and sealed by Parafilm ${ }^{\circledR}$. They were incubated at $(15 \pm 4.5)^{\circ} \mathrm{C}$ in the dark for $1,7,14,28,180$ and 365 days. The storage temperature slightly fluctuated according to the four seasons, with the highest temperatures at day 1 and day 365 (Summer) and the lowest temperatures at day 180 (Winter). Water evaporation was determined gravimetrically and then compensated with the addition of ultrapure water. Samples were finally stored at $-20^{\circ} \mathrm{C}$. For analyses, samples were defrosted by incubation overnight at $6{ }^{\circ} \mathrm{C}$. 


\section{DNA extraction}

DNA extraction and purification were performed using the Genomic DNA from soil kit (Macherey-Nagel, Düren, Germany) according to the manufacturer's instructions and stored at $-20^{\circ} \mathrm{C}$.

\section{Quantitative detection of bacterial phyla genes}

The bacterial taxa Acidobacteria [27, 28], Actinobacteria [28, 29], Bacteroidetes [28, 30], alpha-Proteobacteria [31] and beta-Proteobacteria [32, 33] were quantified using the taxon-specific $16 \mathrm{~S}$ rRNA qPCR assays listed in Table 1. All qPCR reactions were conducted on a thermal cycler equipped with an optical module (Analytik Jena, Jena, Germany). All samples were run in triplicate wells. Single qPCR reactions were prepared in a total volume of $20 \mu \mathrm{L}$. The InnuMix SYBR-Green qPCR Master-Mix was purchased from Analytik Jena (Jena, Germany). Primer concentrations were $10 \mathrm{pmol} / \mu \mathrm{L}$, and amplification specificity was assessed by melting curve analysis and gel electrophoresis on an 1.5\% agarose gel after qPCR. Standard curves were based on cloned PCR products from the respective genes [28] (Table 1).

\section{Statistical analyses}

All data were processed using IBM SPSS Statistics for Windows, Version 23.0 (IBM Corp., Armonk, USA). The obtained qPCR values (copy gene/kg dry soil) of negative controls $(0.00 \mathrm{mg} \mathrm{Ag} / \mathrm{kg})$ were averaged for each phylum and day. Subsequent, the relative variation of a silver treated sample of one concentration and one sampling date were calculated as follow:

For the effect assessment of AgNP and $\mathrm{Ag}^{+}$exposure in dependence of silver concentration, the applied test concentrations of AgNP and $\mathrm{Ag}^{+}$were set as independent variables, whereas the relative variations of

Table 1 PCR primers and cycling conditions used for quantification of the different phyla

\begin{tabular}{|c|c|c|c|c|c|c|c|c|c|}
\hline \multirow{3}{*}{$\begin{array}{l}\text { Phylum } \\
\text { Acidobacteria }\end{array}$} & \multirow{3}{*}{$\begin{array}{l}\text { Primer } \\
\text { Acid31 }\end{array}$} & \multirow{3}{*}{$\begin{array}{l}\text { Primer sequence } \mathbf{5}^{\prime} \mathbf{- 3}^{\prime} \\
\text { GAT CCT GGC TCA } \\
\text { GAATC }\end{array}$} & \multirow{3}{*}{$\begin{array}{l}\text { References } \\
\text { Barns et al. [27] }\end{array}$} & \multirow{3}{*}{$\begin{array}{l}\begin{array}{l}\text { Organism } \\
\text { for standard }\end{array} \\
\text { Acidobacterium capsu- } \\
\text { latum }\end{array}$} & \multicolumn{2}{|c|}{ Reaction mixture } & \multicolumn{3}{|c|}{$\begin{array}{l}\text { Temperature } \\
\text { programme }\end{array}$} \\
\hline & & & & & Acid31 & $2 \mu \mathrm{L}$ & $95^{\circ} \mathrm{C}$ & $15 \mathrm{~min}$ & $\times 1$ \\
\hline & & & & & Eub518 & $2 \mu \mathrm{L}$ & $95^{\circ} \mathrm{C}$ & $15 \mathrm{~s}$ & $\times 35$ \\
\hline & & & & & Sybr Green & $10 \mu \mathrm{L}$ & $55^{\circ} \mathrm{C}$ & $30 s$ & \\
\hline & Eub518 & ATT ACC GCG GCT GCT & Muyzer et al. [28] & & DEPC H2O & $2 \mu \mathrm{L}$ & $72{ }^{\circ} \mathrm{C}$ & $30 s$ & \\
\hline & & & & & DNA & $4 \mu \mathrm{L}$ & $80^{\circ} \mathrm{C}$ & $30 s$ & \\
\hline & & & & & & & $60-95^{\circ} \mathrm{C}$ & & $\times 1$ \\
\hline \multirow[t]{6}{*}{ Actinobacteria } & Actino235 & CGC GGC CTA TCA GCT & Stach et al. [29] & Arthrobacter crystal- & Actino235 & $1.5 \mu \mathrm{L}$ & $95^{\circ} \mathrm{C}$ & $15 \mathrm{~min}$ & $\times 1$ \\
\hline & & TGTTG & & & Eub518 & $1.5 \mu \mathrm{L}$ & $95^{\circ} \mathrm{C}$ & $15 s$ & $\times 35$ \\
\hline & & & & & Sybr Green & $10 \mu \mathrm{L}$ & $60^{\circ} \mathrm{C}$ & $30 s$ & \\
\hline & Eub518 & ATT ACC GCG GCT GCT & Muyzer et al. [28] & & BSA 3\% & $0.4 \mu \mathrm{L}$ & $72^{\circ} \mathrm{C}$ & $30 \mathrm{~s}$ & \\
\hline & & & & & DEPC $\mathrm{H} 2 \mathrm{O}$ & $2.6 \mu \mathrm{L}$ & $80^{\circ} \mathrm{C}$ & $30 s$ & \\
\hline & & & & & DNA & $4 \mu \mathrm{L}$ & $60-95^{\circ} \mathrm{C}$ & & $\times 1$ \\
\hline \multirow[t]{5}{*}{ a-Proteobacteria } & a682F & CNA GTG TAG AGG TGA & De Gregoris et al. [31] & Bradyrhizobium japoni- & $a 682 F$ & $2 \mu \mathrm{L}$ & $95^{\circ} \mathrm{C}$ & $15 \mathrm{~min}$ & $\times 1$ \\
\hline & & AATT & & cum & $908 a R$ & $2 \mu \mathrm{L}$ & $95^{\circ} \mathrm{C}$ & $15 \mathrm{~s}$ & $\times 35$ \\
\hline & & & & & Sybr Green & $10 \mu \mathrm{L}$ & $61.5^{\circ} \mathrm{C}$ & $15 s$ & \\
\hline & $908 a R$ & CCC CGT CAA TTC CTT & & & DEPC H2O & $2 \mu \mathrm{L}$ & $72^{\circ} \mathrm{C}$ & $20 \mathrm{~s}$ & \\
\hline & & TGA GTT & & & DNA & $4 \mu \mathrm{L}$ & $60-95^{\circ} \mathrm{C}$ & & $\times 1$ \\
\hline \multirow[t]{6}{*}{ Bacteroidetes } & Cfb319 & GTA CTG AGA CAC GGA & Manz et al. [30] & Flavobacterium aquatile & Cfb319 & $2 \mu \mathrm{L}$ & $95^{\circ} \mathrm{C}$ & $15 \min$ & $\times 1$ \\
\hline & & & & & Eub518 & $2 \mu \mathrm{L}$ & $95^{\circ} \mathrm{C}$ & $15 \mathrm{~s}$ & $\times 35$ \\
\hline & & & & & Sybr Green & $10 \mu \mathrm{L}$ & $60^{\circ} \mathrm{C}$ & $30 s$ & \\
\hline & Eub518 & ATT ACC GCG GCT GCT & Muyzer et al. [28] & & DEPC H2O & $2 \mu \mathrm{L}$ & $72^{\circ} \mathrm{C}$ & $30 s$ & \\
\hline & & & & & DNA & $4 \mu \mathrm{L}$ & $80^{\circ} \mathrm{C}$ & $30 s$ & \\
\hline & & & & & & & $60-95^{\circ} \mathrm{C}$ & & $\times 1$ \\
\hline \multirow[t]{6}{*}{$\beta$-Proteobacteria } & Eub338 & ACT CCT ACG GGA GGC & Overmann et al. [32] & Alcaligenes faecalis & Bet680 & $2 \mu \mathrm{L}$ & $95^{\circ} \mathrm{C}$ & $15 \min$ & $\times 1$ \\
\hline & & AGC AG & & & Eub338 & $2 \mu \mathrm{L}$ & $95^{\circ} \mathrm{C}$ & $15 \mathrm{~s}$ & $\times 35$ \\
\hline & & & & & Sybr Green & $10 \mu \mathrm{L}$ & $55^{\circ} \mathrm{C}$ & $30 s$ & \\
\hline & Bet680 & TCA CTG CTA CAC GYG & Lane [33] & & DEPC H2O & $2 \mu \mathrm{L}$ & $72{ }^{\circ} \mathrm{C}$ & $30 s$ & \\
\hline & & & & & DNS & $4 \mu \mathrm{L}$ & $80^{\circ} \mathrm{C}$ & $30 s$ & \\
\hline & & & & & & & $60-95^{\circ} \mathrm{C}$ & & $\times 1$ \\
\hline
\end{tabular}


Acidobacteria, Actinobacteria, alpha-Proteobacteria, Bacteroidetes and beta-Proteobacteria were treated as dependent variables. For the effect assessment of AgNP and $\mathrm{Ag}^{+}$exposure in dependence of sampling date, the sampling days ( 1 day-365 days) were set as independent variables, whereas the relative variations of different phyla at one test concentration were treated as dependent variables.

For each test concentration and day, 4 replicates per phylum were measured, and the average, median and standard deviation were calculated for these groups. In the following, groups were pre-evaluated for a normal distribution by the Shapiro-Wilk test. Variance homogeneity between the groups to be compared was calculated by the Levene test. The effects of different AgNP and $\mathrm{Ag}^{+}$ concentrations on 1 day and the effects of sampling date of one $\mathrm{AgNP}$ and $\mathrm{Ag}^{+}$concentration, respectively, were compared with the ANOVA and Kruskal-Wallis test. Subsequent post hoc tests were performed by pairwise comparisons using the Dunn-Bonferroni or GamesHowell tests, depending on the requirements. Linear regression (least squares) and bivariate correlation (Pearson) were conducted for groups with homoscedasticity. For groups displaying heteroscedasticity, linear regression and bivariate correlation analyses were performed by weighted least squares (WLS).

\section{Results}

\section{Test concentrations of AgNP and $\mathrm{Ag}^{+}$}

For the effect assessment of AgNP and $\mathrm{Ag}^{+}$exposure in dependence of silver concentrations, the applied test concentrations of $\mathrm{AgNP}$ and $\mathrm{AgNO}_{3}$ were compared to the relative variations of Acidobacteria, Actinobacteria, alpha-Proteobacteria, Bacteroidetes and beta-Proteobacteria at one sampling date.

\section{Short-term exposure: 1-day exposure}

Short-term exposure of 1 day caused significant positive effects on Acidobacteria (43.95\%), Actinobacteria (21.1\%) and Bacteroidetes (14.6\%) due to $0.01 \mathrm{mg} \mathrm{AgNP} / \mathrm{kg}$, whereas beta-Proteobacteria population was decreased by $14.15 \%$ relative to the control (Table 2). Results of $\mathrm{Ag}^{+}$ exposure in the form of $\mathrm{AgNO}_{3}$ revealed similar effects at $0.01 \mathrm{mg} \mathrm{Ag} / \mathrm{kg}$ for Acidobacteria and Bacteroidetes (Table 2). At higher AgNP concentrations (0.1-1 mg AgNP/kg) Acidobacteria, Actinobacteria and betaProteobacteria were unaffected, whereas Bacteroidetes population increased by around $19 \%(p=0.015)$. Higher $\mathrm{Ag}^{+}$concentrations caused no effects on Acidobacteria, whereas the Bacteroidetes population was significantly stimulated by $40.0 \%(p=0.000)$ relative to the control. The S16 rRNA copy numbers of beta-Proteobacteria significantly decreased at 0.1 and $1.0 \mathrm{mg} \mathrm{Ag}^{+} / \mathrm{kg}$ by $30.5 \%$ $(p=0.000)$ and $17.9 \%(p=0.020)$, respectively (Table 2$).$ The response of Actinobacteria was ambiguous (Table 2). Alpha-Proteobacteria showed no significant response to the tested $\mathrm{AgNP}$ and $\mathrm{Ag}^{+}$concentrations on day 1 .

\section{Mid-term exposure: 14-28 days of exposure}

After 1 week, AgNP and $\mathrm{Ag}^{+}$exposure caused similar significantly positive effects on Bacteroidetes like on day $1(p=0.000)$ (Table 2). Alpha- and beta-Proteobacteria were significantly diminished by $17.8 \%(p=0.011)$ and $28.4 \%(p=0.000)$ at $0.01 \mathrm{mg} \mathrm{AgNP} / \mathrm{kg}$. Furthermore, beta-Proteobacteria population decreased due to $1.0 \mathrm{mg}$ $\mathrm{AgNP} / \mathrm{kg}$ exposure on day 7 ( $p=0.002)$, whereas $1.0 \mathrm{mg}$ $\mathrm{Ag}^{+} / \mathrm{kg}$ increased the beta-proteobacterial population by $46.0 \%(p=0.000)$ relative to the control. Acido- and Actinobacteria were unaffected at this sampling point in regard to silver treatments.

In the following weeks, both AgNP and $\mathrm{Ag}^{+}$caused notable effects on Acidobacteria and Actinobacteria (Table 2). At day 14, AgNP reduced the populations of alpha-, beta-Proteobacteria and Bacteroidetes $(p<0.05)$, whereas these groups were unaffected due to $\mathrm{Ag}^{+}$. After 1 month, exposure of AgNP caused no further effects on alpha-Proteobacteria and Bacteroidetes. Beta-Proteobacteria population was significantly minimized at 0.01 $(p=0.001)$ as well as $0.1 \mathrm{mg} \mathrm{AgNP} / \mathrm{kg}(p=0.003)$ and, in contrast, enlarged by $1.0 \mathrm{mg} \mathrm{Ag}^{+} / \mathrm{kg}(p=0.007)$ (Table 2$)$.

\section{Long-term exposure: 90-365 days of exposure}

At day 90, AgNP and $\mathrm{Ag}^{+}$exposure led to significant decreases of all phyla populations (Table 2). The relative variations to the negative control documented tendentially stronger or equal impacts of AgNP in relation to $\mathrm{Ag}^{+}$(Table 2). For instance, tested nanoparticulate silver concentrations on day 90 caused an averaged decrease by $27.2 \%$ of actinobacterial population, whereas ionic silver concentrations caused an averaged decrease by $22.8 \%$. With exception of the beta-Proteobacteria population, this trend inversed at day 180 and $\mathrm{Ag}^{+}$influenced population sizes more intensive compared to AgNP (Table 2). Now, AgNP had no more effects on Acidobacteria, whereas $\mathrm{Ag}^{+}$reduced Acidobacteria population by averaged $16.4 \%$.

At the end of the long-term experiment at day 365, effects due to AgNP were still remarkable. As litthe as $0.01 \mathrm{mg}$ AgNP/ $/ \mathrm{kg}$ diminished Acidobacteria $(p=0.007)$, Bacteroidetes $(p=0.005)$ and beta-Proteobacteria $(p=0.000)$ by $14.5,10.1$ and $13.9 \%$, respectively (Table 2). The equal concentration of $\mathrm{Ag}^{+}$ caused no effect, decrease by $25.78 \%$ and nearly the same decrease of $14.8 \%$ for the groups, respectively (Table 2). Finally, the averaged effects of the tested concentrations were the highest for beta-Proteobacteria 


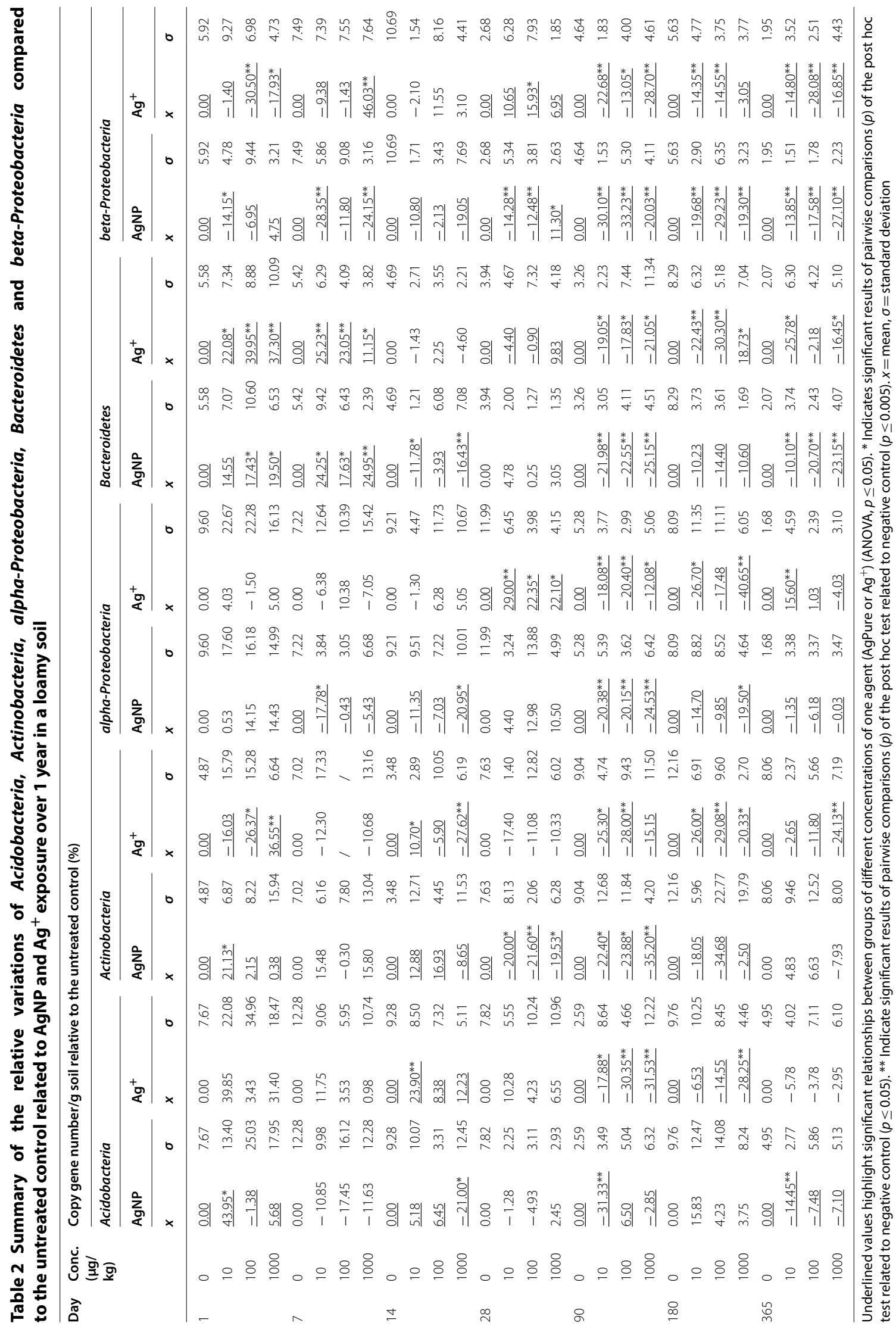


and Bacteroidetes, which showed significant decline of $19.5 \%$ by $\mathrm{AgNP}$ and $19.9 \%$ by $\mathrm{Ag}^{+}$as well as $18.0 \%$ by AgNP and $14.8 \%$ by $\mathrm{Ag}^{+}$, respectively. Actino- and alpha-Proteobacteria were statistically unaffected by AgNP treatments after 1-year exposure (Table 2), whereas $\mathrm{Ag}^{+}$treatments significantly reduced or stimulated their populations, respectively (Table 2 ).

\section{Exposure time of AgNP and $\mathrm{Ag}^{+}$}

For the effect assessment of AgNP and $\mathrm{Ag}^{+}$exposure in dependence of sampling date, the sampling days (1 day-365 days) were compared to the relative variations of the different phyla at one test concentration. In Figs. 1 and 2, the temporal progress of relative variations for each phylum at different concentrations, 0.01 (a), 0.10 (b) and 1.00 (c), of AgNP and $\mathrm{Ag}^{+}$was visualized.

Hypothesis tests revealed that the exposure time of $\mathrm{AgNP}$ and $\mathrm{Ag}^{+}$had consistent significant effects on the relative variations of the bacterial population sizes of each phylum at each concentration $(p<0.025)$. For example, AgPure treatment of $0.01 \mathrm{mg} \mathrm{AgNP} / \mathrm{kg}$ soil created different effect characteristics on the relative variations of Actinobacteria in dependence on sampling date. Here, ANOVA analysis indicated a $p$ value of 0.000 between the groups of $1,7,14,28,90,180$ and 365 days. Results of the post hoc test are shown in Table 3.

Linear regression and correlation analysis showed only one moderate correlation $\left(r^{2}=0.537\right)$ between the relative variation of the rRNA copy number in relation to the untreated control and the sampling date for Bacteroidetes exposure to $0.01 \mathrm{mg} \mathrm{Ag} / \mathrm{kg}(p=0.000)$. The linear regression and correlation analyses to reveal potential relationships between the relative variation and sampling time for the remaining phyla showed only very weak significant correlations or were not significant (data not shown). Thus, the majority of the temporal progresses of relative variations for each phylum at the different concentrations did not follow linear relationships about the exposure period of 1 year.

However, linear regression and correlation analysis between the relative variation of the rRNA copy number and the sampling dates between day 90 and 365 revealed 18 out of 30 possible significant linear regressions $(p<0.05)$ (Table 4). Especially in case of AgNP, there seemed to be a strong time dependence of toxicity. Only in case of Acidobacteria-0.1 mg AgPure $/ \mathrm{kg}$ and Bacteroidetes- $-0.01 \mathrm{mg} \mathrm{Ag} / \mathrm{kg}$, the relationships were negative correlated. Regarding to Acidobacteria, $r^{2}$ - and $p$-values of 0.356 and 0.040 were indicative of a weak correlation. In the cases of the majority of the linear regressions, the toxicity of silver agents decreased significantly with time.

\section{Discussion}

Soil bacteria are involved in major soil processes, such as humification, recycling, mineralization of organic matter and stabilization of soil structure [25]. Although linking members of bacterial communities in soils with their function has proven to be still difficult through their phylogenetically diversity [34], not cultivability [35] and functional redundancy [36], some substantial soil functions could be dedicated to specific soil bacteria phyla. For instance, beta-Proteobacteria were linked to autotrophic ammonia oxidation (nitrification) [37], Actinobacteria to decomposition and humus formation [21], Acidobacteria to organic carbon transformation [20, 38, 39], alpha-Proteobacteria to $\mathrm{CO}_{2}$-fixation, carbon degradation and sulphur cycling [38], and Bacteroidetes to chitin degradation [38] in soils.

Furthermore, certain bacteria phyla could be used as indicators of nutrient status, soil acidity, soil pollution and changes of other environmental factors [40, 41]. Here, we discuss the abundance of five different bacterial phyla in dependence of different nanoparticulate and ionic silver concentrations, as well as of the exposure time.

\section{Short-term exposure: 1-day exposure}

Short-term exposure of $\mathrm{Ag}^{+}$caused predominantly stronger effects on the investigated populations compared to AgNP (Table 2). These distinct effect responses in case of the two silver forms were indicative of their time-dependent reactivity in the complex physicochemical soil system. Assuming that $\mathrm{Ag}^{+}$ions released by AgNP caused the effects on day 1, the dissolution of AgNP after short-term exposure took more time in contrast to $\mathrm{Ag}^{+}$ released by $\mathrm{AgNO}_{3}$. Several studies [8, 42-44] documented a slow and progressive increase in AgNP toxicity with time and assumed a time-dependent enlargement of silver ions due to slow dissolution. Dissolution of AgNP in soils is influenced by oxidation [45] and surface blocking induced by organic matter and mineral phase constituents [42]. Here, dissolution of the AgNP was certainly, because the high concentration of divalent cations, such as $\mathrm{Ca}^{2+}$ und $\mathrm{Mg}^{2+}$, in the Stagno-Luvisol promoted AgNP dissolution, resulting in the displacement of $\mathrm{Ag}^{+}$ ions from the nanoparticle surface [46]. Moreover, the dissolution hypothesis was also supported by the low concentrations of AgNP in the test soil, their polyacrylate stabilization and the high $\mathrm{pH}$ value of soil that could have prevented initial aggregation and agglomeration of AgNP [47]. Apart from that, soil inhibits the release of $\mathrm{Ag}^{+}$ions 
Acidobacteria $\mathbb{Q}$ Actinobacteria $\square$ alpha-Proteobacteria

Bacteroidetes 㖆 beta-Proteobacteria
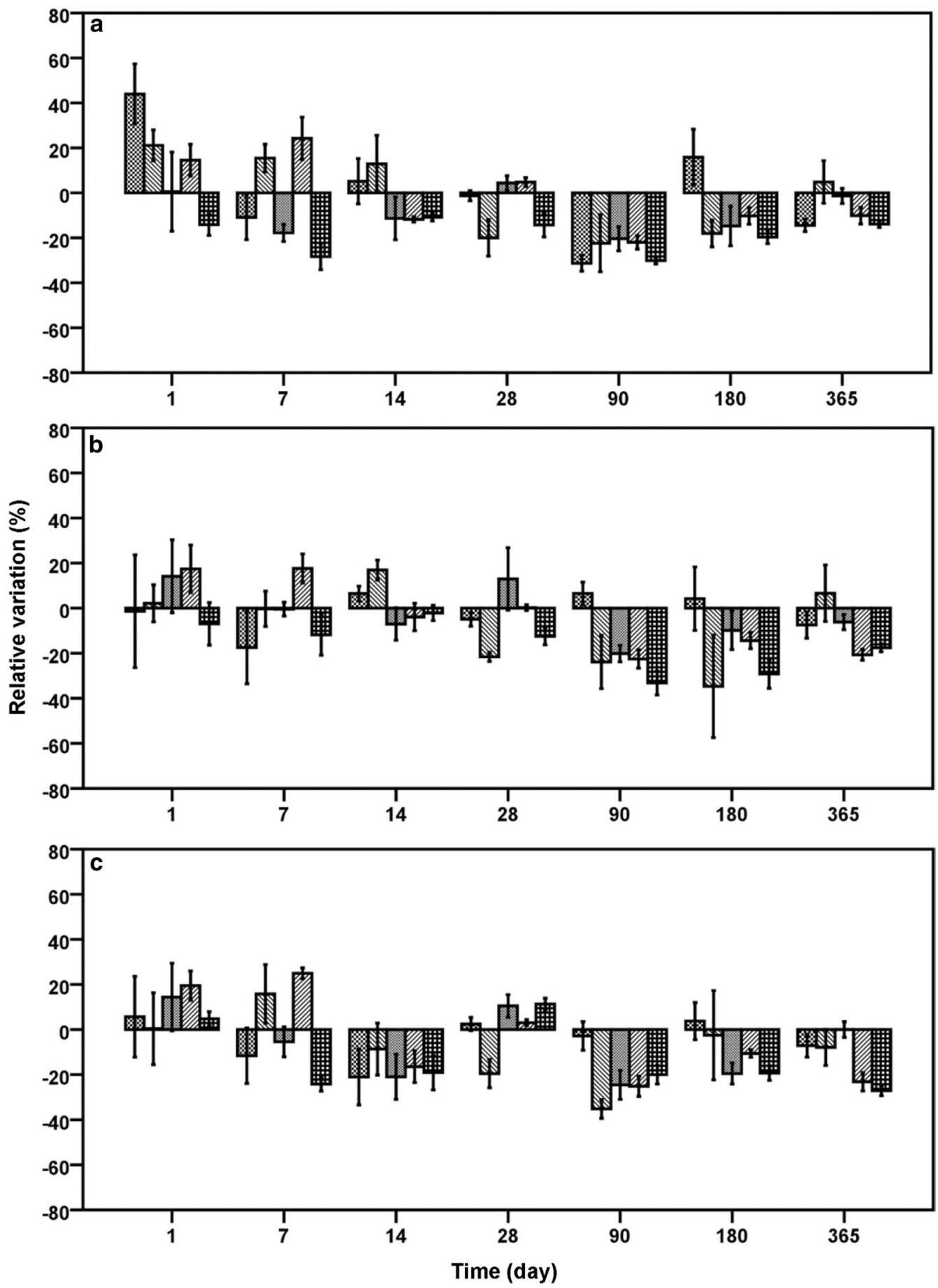

Fig. 1 Relative variations of Acidobacteria, Actinobacteria, alpha-Proteobacteria, Bacteroidetes and beta-Proteobacteria compared to untreated control related to time at different AgNP concentrations. a $0.01 \mathrm{mg} \mathrm{AgNP} / \mathrm{kg}, \mathbf{b} 0.10 \mathrm{mg} \mathrm{AgNP} / \mathrm{kg}, \mathbf{c} 1.00 \mathrm{mg} \mathrm{AgNP} / \mathrm{kg}$ 
Acidobacteria $\mathbb{W}$ Actinobacteria $\square$ alpha-Proteobacteria

Bacteroidetes 䀳 beta-Proteobacteria
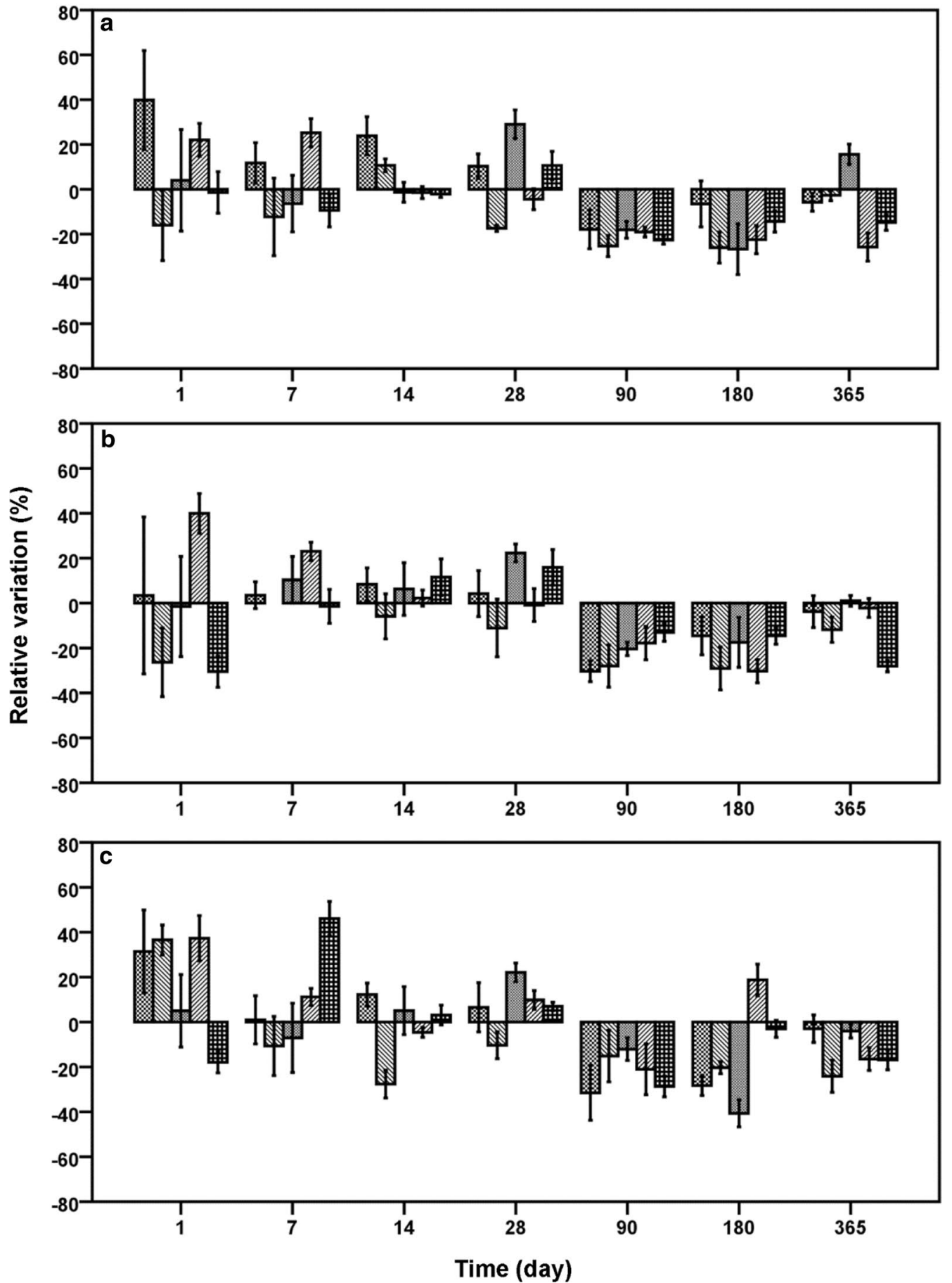

Fig. 2 Relative variations of Acidobacteria, Actinobacteria, alpha-Proteobacteria, Bacteroidetes and beta-Proteobacteria compared to untreated control related to time at different $\mathrm{Ag}^{+}$concentrations. a $0.01 \mathrm{mg} \mathrm{Ag}^{+} \mathrm{kg}^{-1}, \mathbf{b} 0.10 \mathrm{mg} \mathrm{Ag}^{+} \mathrm{kg}^{-1}, \mathbf{c} 1.00 \mathrm{mg} \mathrm{Ag} \mathrm{kg}^{-1}$ 
Table 3 Pairwise comparisons $(p)$ of the post hoc test for comparing the relative variations of Actinobacteria relative to untreated control at $0.01 \mathrm{mg} \mathrm{AgNP/kg}$ in dependence of sampling day

\begin{tabular}{llllllll}
\hline Sampling date $[\mathbf{d}]$ & $\mathbf{1}$ & $\mathbf{7}$ & $\mathbf{1 4}$ & $\mathbf{2 8}$ & $\mathbf{9 0}$ & $\mathbf{1 8 0}$ & $\mathbf{3 6 5}$ \\
\hline 1 & & $/$ & $/$ & 0.000 & 0.000 & 0.000 & 0.001 \\
7 & $/$ & $/$ & 0.000 & 0.000 & $/$ & 0.002 \\
14 & $/$ & 0.000 & 0.001 & 0.001 & 0.000 & $/$ \\
28 & 0.000 & 0.000 & 0.000 & $/$ & $/$ & 0.022 \\
90 & 0.000 & 0.001 & 0.002 & $/$ & $/$ & 0.009 \\
180 & 0.000 & $/$ & $/$ & 0.022 & 0.009 & 0.045 \\
365 & $/$ & $/$ & & & & \\
\hline
\end{tabular}

Only significant pairs were stated by their p value. In case of "/" no significant comparison could be observed

Table 4 Results of Pearson correlation analysis for comparing the relative variations of the phyla at different AgNP and $\mathrm{Ag}^{+}$concentrations in dependence of exposure time between 90 and 365 days

\begin{tabular}{|c|c|c|c|c|c|c|c|c|c|c|c|}
\hline & \multirow[t]{2}{*}{$\mu \mathrm{g} / \mathrm{kg}$} & \multicolumn{2}{|c|}{ Acidobacteria } & \multicolumn{2}{|c|}{ Actinobacteria } & \multicolumn{2}{|c|}{ Alpha-Proteobacteria } & \multicolumn{2}{|c|}{ Bacteroidetes } & \multicolumn{2}{|c|}{$\begin{array}{l}\text { Beta- } \\
\text { Proteobacteria }\end{array}$} \\
\hline & & $r^{2}$ & $p$ & $r^{2}$ & $p$ & $r^{2}$ & $p$ & $r^{2}$ & $p$ & $r^{2}$ & $p$ \\
\hline \multirow[t]{3}{*}{ AgPure } & 10 & / & / & 0.646 & 0.002 & 0.682 & 0.001 & 0.441 & 0.018 & 0.818 & 0.000 \\
\hline & 100 & $0.356^{*}$ & $0.040^{*}$ & 0.419 & 0.023 & 0.472 & 0.014 & / & / & 0.707 & 0.001 \\
\hline & 1000 & / & / & / & / & 0.842 & 0.000 & / & / & 0.508 & 0.009 \\
\hline \multirow[t]{3}{*}{$\mathrm{Ag}^{+}$} & 10 & / & / & 0.758 & 0.000 & 0.670 & 0.001 & / & / & / & / \\
\hline & 100 & 0.699 & 0.001 & 0.465 & 0.015 & 0.694 & 0.001 & $0.421^{*}$ & $0.023^{*}$ & 0.788 & 0.000 \\
\hline & 1000 & 0.723 & 0.000 & / & / & / & / & / & / & / & / \\
\hline
\end{tabular}

Negative correlations were marked by a star. In case of "/" no significant comparison could be observed

due to organic matter coatings [48]. Consequently, the combination of dissolution and stability of AgNP led to lower effect strength.

Both AgNP and $\mathrm{Ag}^{+}$chiefly provoked similar effects on Acidobacteria, Bacteroidetes and beta-Proteobacteria in the respective silver concentration. Acidobacteria and Bacteroidetes were generally stimulated, whereas beta-Proteobacteria was primarily diminished by silver addition. The effect strengths were in general higher for $\mathrm{Ag}^{+}$compared to AgNP. Actually, Acidobacteria are known for their AgNP intolerance in soils [16, 17, 19, 49]. Here, they were significantly stimulated after 1-day exposure to environmentally relevant concentration of $0.01 \mathrm{mg} \mathrm{AgNP} / \mathrm{kg}$. With increasing concentrations, the effect strength diminished (Table 2). The extrusion of heavy metal ions by efflux systems, the reduction into less toxic oxidative states and the production of extracellular proteins or polysaccharides are common bacterial metal resistance mechanisms [50-52]. Ward et al. [39] reported a variety of ion channels, excretion of extracellular slime and resistance-nodulation-cell division transporter system for Acidobacteria, which could explain the acidobacterial AgNP tolerance. Furthermore, Yang et al. [53] found silver tolerance genes in acidobacterial genera. In addition, hormone-like responses to low silver concentrations were reported as a reason for stimulatory effects due to AgNP exposure $[54,55]$. The previously observed contrasting acidobacterial AgNP intolerance by e.g. Juan et al. [16] or McGee et al. [17] might be the result of their high test concentrations of 10 to $100 \mathrm{mg}$ AgNP/ $/ \mathrm{kg}$ soil, which could prevent metal resistance mechanisms and hormone-like responses. The stimulation of Bacteroidetes due to nanoparticulate and ionic silver addition was in agreement with previous observations [16, 17, 19, 53, 56]. They exhibit also silver resistance genes [53]. Members of beta-Proteobacteria harbour likewise silver resistance genes [53], which could be the underlying reason for non-observable effects at concentrations higher than $0.01 \mathrm{mg} \mathrm{AgNP} / \mathrm{kg}$. Apart from that, 0.1 and $1.0 \mathrm{mg} \mathrm{Ag} / \mathrm{kg}$ significantly lowered the beta-proteobacterial population after short-term exposure (Table 2). Thus, it seemed to be more probable that the effects were caused by $\mathrm{Ag}^{+}$again, and dissolution of AgNP needed more time compared to $\mathrm{AgNO}_{3}$. At the environmentally relevant concentration of $0.01 \mathrm{mg}$ AgNP $/ \mathrm{kg}$, a significantly decrease of beta-Proteobacteria by $14.2 \%(p=0.047)$ was observed, whereas $\mathrm{Ag}^{+}$caused no effects. Here, it might be possible that AgNP directly impacted beta-Proteobacteria by effecting cell walls and membranes, the production of reactive oxygen species 
(ROS) and modifications of nucleic acids. Furthermore, the decrease of beta-Proteobacteria at $0.01 \mathrm{mg} \mathrm{AgNP} / \mathrm{kg}$ could be an evidence for an expression threshold of silver resistance genes. Because AgNP showed slower dissolution, the $\mathrm{Ag}^{+}$concentration was not sufficient for the expression of silver resistance genes and $\mathrm{Ag}^{+}$could inhibit the respiratory chain, collapse the proton motive force, and influence the phosphate uptake and DNA molecules [57] of beta-Proteobacteria.

Alpha-Proteobacteria were statistically unaffected due to $\mathrm{AgNP}$ and $\mathrm{Ag}^{+}$exposure after 1 day. Here, also silver resistance genes could be the underlying reason as well as common bacterial resistance mechanisms [50-52].

The stimulation of Actinobacteria at low AgNP concentrations and the diminution at the same $\mathrm{Ag}^{+}$concentrations (Table 2) were again an evidence for slow AgNP dissolution and $\mathrm{Ag}^{+}$release. The promotion of Actinobacteria at $1.0 \mathrm{mg} \mathrm{AgNP} / \mathrm{kg}$ was indicative for actinobacterial silver resistance mechanism, which needed a threshold concentration to become active. Vasileiadis et al. [58] documented silver resistance possibility for some actinobacterial members.

\section{Mid-term exposure: 14-28 days of exposure}

In contrast to the hypothesis of slow and progressive enlargement of AgNP toxicity with time, the effect strength of AgNP decreased at mid-term exposure between day 7 and 28 (Table 2). The same was observed for $\mathrm{Ag}^{+}$in the form of $\mathrm{AgNO}_{3}$ (Table 2). However, the effect strength of both silver forms became more similar and $\mathrm{Ag}^{+}$showed only small higher effects on the bacterial phyla compared to AgNP. This supports the dissolution hypothesis of $\mathrm{Ag}^{+}$by AgNP, which took more time. The smaller effect strength might be due to interactions of the silver species with the soil compartment. In the environment, AgNP is relatively susceptible to transformations (e.g. changes in aggregation and oxidation state, dissolution, sulfidation, sorption of inorganic and organic species), thus modifying their physical and chemical properties and behaviour $[59,60]$. Moreover several studies indicated that the physicochemical characteristics of soils correlated to various effects by AgNP and thus toxicity $[23,24]$. It is likely that the short-term effects were observed as a result of the initial release of bioavailable $\mathrm{Ag}^{+}$and the AgNP, which could be reduced at later time points due to interactions of the silver species with organic matter, clay minerals or pedogenic oxides. According to previous investigations, high clay content (approximately 30\%) of the Stagnic-Luvisol and high content of organic carbon (2.9\%) could lead to a higher retention of AgNP and $\mathrm{Ag}^{+}$ions a few days after the initial contamination [48, 61-63]. Furthermore, self-protection mechanisms, like the production of extracellular proteins or polysaccharides of the soil microbiome, could neutralize toxic ions or cap AgNP [51, 52]. Also, resilience mechanisms, such as fast growth rates, metabolic flexibility, physiological tolerance [36] and/or cryptic growth [64], might also be possible explanations for the limited effects on the bacterial phyla in the soil. These interactions between soil, silver agents and microbial community influenced the toxicity to such an extent that a linear relationship between time and toxicity could not be observed (Figs. 1 and 2). Nevertheless, the pairwise comparisons of post hoc tests for comparing the relative variations relative to untreated control at different silver concentrations in dependence of sampling day distinctly proved a strong relationship between exposure time and toxicity.

Focusing on the individual bacterial groups revealed overall no significant effects on Acidobacteria after exposure to nanoparticulate as well as ionic silver for 7 to 28 days (Table 2). Apart from the already stated acidobacterial silver resistance mechanisms, a shift in their community structure towards more silver-tolerant species could be probable [53]. Additionally, Ulrich and Becker [65] documented that Acidobacteria seemed to participate frequently in the shifting of community structures that result from soil property changes. Only $1.0 \mathrm{mg}$ AgNP $/ \mathrm{kg}$ caused a significantly decrease of Acidobacteria after 14 days $(p=0.049)$, but the acidobacterial population recover until day 28 probable due to resilience mechanisms.

Actinobacteria seemed also statistically unaffected by $\mathrm{Ag}^{+}$and AgNP after 1-week exposure, but commencing with day 14, significant decreases of actinobacterial communities were observed. The effect strengths for both silver species were very similar, leading to the assumption of $\mathrm{Ag}^{+}$as toxicological agent. In contrast to the stated actinobacterial silver resistance possibility, Vasileiadis et al. [58] as well as Juan et al. [16] noticed sensitivity against silver, which could be confirmed in our study. The copy number of alpha- and beta-Proteobacteria as well as of Bacteroidetes relative to the untreated controls showed distinct and changeable responses to mid-term silver additions (Table 2). These periodic and concentration-dependent fluctuations could be attributed to the physiological and ecological diversity of the members of one phylogenetic group as well as to the soil and agent interactions in a complex space-time framework. Nevertheless, after 1-month exposure, Bacteroidetes were unaffected by AgNP and $\mathrm{Ag}^{+}$(Table 2). McGee et al. [17] monitored a similar resistance of Bacteroidetes after exposure to $50 \mathrm{mg} \mathrm{AgNP}(20 \mathrm{~nm}) / \mathrm{kg}$ soil after 30 days in soil. The alpha-Proteobacteria population was also unaffected by AgNP, but showed a significantly growth due to $\mathrm{Ag}^{+}$treatment (Table 2). Previous studies documented 
alpha-proteobacterial increase due to low metal concentrations [66, 67]. Furthermore, alpha-Proteobacteria are known as ecological most diverse group [40]. Therefore, a shift within the alpha-proteobacterial population due to silver exposure could have unpredictable effects on $\mathrm{CO}_{2}$ fixation, carbon degradation and sulphur transformation by their colonization of new ecological niches in consequence of silver emission into soils.

The rise of beta-Proteobacteria due to $\mathrm{Ag}^{+}$(Table 2) was consistent with our previous study [8], indicating a stimulation of beta-proteobacterial ammonia oxidizers by hormone-like responses to low silver concentrations $[54,55]$ The stimulation of beta-proteobacterial ammonia oxidizers on the one hand and the sensitivity of the overall beta-Proteobacteria population due to AgNP on the other hand (Table 2) were indicative for distinct susceptibilities among the members of this class. While the amoA-harbouring genera Nitrosomonas and Nitrosospira seemed to be more AgNP tolerant, other genera or species of this group were very sensitive. A more precise study is essential for resolving this observation.

\section{Long-term exposure: 90-365 days of exposure}

Similar to our observations concerning the impact of AgNP and $\mathrm{Ag}^{+}$on microbial biomass, enzyme activity and functional genes involved in the nitrogen cycle of loamy soil [8], long-term exposure starting at exposure day 90 led to significant ecotoxicity (Table 2). Ageing of both silver forms and their slow return to the biological soil system presented a continuous sinking of bioavailable silver. As already mentioned, an increase in AgNP toxicity with time can be linked to time-dependent enlargement of silver in soil pore water due to dissolution $[42,68]$. The interplay of nanoparticulate and ionic silver effect strength demonstrated the toxicity of $\mathrm{Ag}^{+}$ions, if silver nitrate caused stronger effects, and if soil conditions inhibit $\mathrm{Ag}^{+}$release, soil-aged AgNP may still act as a sink for bioavailable silver, as $\mathrm{Ag}^{+}$ions absorbed on the particle surface may be released into the soil system [48]. Interestingly, the toxicity of AgNP as well as $\mathrm{Ag}^{+}$predominantly decreased significantly with ongoing exposure time between 90 and 365 days (Table 2, Table 4). There seemed to be a shock load of silver on day 90 to which the bacterial groups were not immediately prepared. Based on our data, we could only speculate about this event. The intricacy of soil and agent interactions in the complex space-time framework influenced the silver toxicity mechanisms. Small-scale bioavailability, chemical alterations and possible transformations (aggregation, dissolution, sulfidation, sorption) of AgNP and $\mathrm{Ag}^{+}$[59, 69] in the Luvisol are only a few possible physicochemical causes. Nevertheless, the decline of silver toxicity on the bacterial phyla at day 180 and 365 indicated again silver resistance and resilience mechanisms as described above. It might be assumed that after short- and mid-term adaption to the silver contamination as well as the positioning of the silver species in the soil system, the bacterial population might have lost its silver tolerance and were unanticipatedly shocked the return of silver toxicant at day 90 resulting in strong population reductions. Not until then, bacteria could replenish their arsenal of defense mechanisms and the toxicity of silver particles could be reduced. Nevertheless, the silver effects were stronger compared to short- and mid-term exposure, indicating indeed soil as a continuous sink of bioavailable silver.

\section{Conclusion}

Changes of the relative abundance of Acidobacteria, Actinobacteria, alpha- and beta-Proteobacteria as well as for Bacteroidetes along AgNP concentrations ranging from 0.01 to $1 \mathrm{mg} \mathrm{AgNP} / \mathrm{kg}$ soil over a long-term period of 1 year using a loamy soil were analysed by $16 \mathrm{~S}$ rRNA qPCR technique. After 1-year exposure, we found that the abundances of Acidobacteria, Bacteroidetes and beta-Proteobacteria were significantly diminished after long-term exposure to environmentally relevant concentration of $0.01 \mathrm{mg} \mathrm{AgNP} / \mathrm{kg}$ loamy soil. Actino- and alpha-Proteobacteria were statistically unaffected by AgNP treatments after 1-year exposure. Thus, even very low concentrations of AgNP may cause disadvantages for the autotrophic ammonia oxidation (nitrification), the organic carbon transformation and the chitin degradation in soils by exerting harmful effects on the liable bacterial phyla.

Furthermore, the statistically significant relationships between silver toxicity and exposure time presented loamy soils as a sink for silver nanoparticles and their concomitant silver ions.

\section{Additional file}

\section{Additional file 1.}

\section{Authors' contributions}

GAL analysed the data and wrote the manuscript. EC designed and performed the experiments. Both authors read and approved the final manuscript.

\section{Acknowledgements}

We appreciate Elvira Sieberger (University of Trier) for her excellent laboratory support and assistance. Many thanks are dedicated to Varentta Audu for proofreading.

Competing interests

The authors declare that they have no competing interests. 


\section{Availability of data and materials}

All datasets on which the conclusions of the paper rely are presented in the main manuscript (Additional file 1).

\section{Consent for publication}

Not applicable.

\section{Ethics approval and consent to participate}

Not applicable.

\section{Funding}

The study was financially supported by the BMBF, grant No. 03X0150C within the research project 'NanoUmwelt'.

\section{Publisher's Note}

Springer Nature remains neutral with regard to jurisdictional claims in published maps and institutional affiliations.

Received: 2 July 2018 Accepted: 20 August 2018

Published online: 31 August 2018

\section{References}

1. Reidy B, Haase A, Luch A, Dawson K, Lynch I (2013) Mechanisms of silver nanoparticle release, transformation and toxicity: a critical review of current knowledge and recommendations for future studies and applications. Materials 6:2295-2350

2. Hänsch M, Emmerling C (2010) Effects of silver nanoparticles on the microbiota and enzyme activity in soil. J Plant Nutr Soil Sci 173:554-558

3. Nowack B (2010) Nanosilver revisited downstream. Science 330:1054-1055

4. Sun TY, Gottschalk F, Hungerbühler K, Nowack B (2014) Comprehensive probabilistic modelling of environmental emissions of engineered nanomaterials. Environ Pollut 185:69-76

5. Gottschalk F, Sonderer T, Scholz RW, Nowack B (2009) Modeled environmental concentrations of engineered nanomaterials (TiO2, ZnO, Ag, CNT, Fullerenes) for different regions. Environ Sci Technol 43:9216-9222

6. Maillard JY, Hartemann P (2013) Silver as an antimicrobial: facts and gaps in knowledge. Crit Rev Microbiol 39:373-383

7. Judy JD, Bertsch PM (2014) Bioavailability, Toxicity, and fate of manufactured nanomaterials in terrestrial ecosystems. In: Spark DL (ed) Advances in agronomy, vol 123. Academic Press. Cambridge, Massachusetts, pp $1-64$

8. Grün A-L, Straskraba S, Schulz S, Schloter M, Emmerling C (2018) Longterm effects of environmentally relevant concentrations of silver nanoparticles on microbial biomass, enzyme activity, and functional genes involved in the nitrogen cycle of loamy soil. J Environ Sci 69:12-22

9. Gregorich E, Monreal C, Carter M, Angers D, Ellert B (1994) Towards a minimum data set to assess soil organic matter quality in agricultural soils. Can J Soil Sci 74:367-385

10. Turco RF, Kennedy AC, Jawson MD (1994) Microbial indicators of soil quality. In: Doran JW, Coleman DC, Bezdicek DF, Stewart BA (eds) Defining soil quality for a sustainable environment. Purdue Univ, Lafayette

11. Holden PA, Schimel JP, Godwin HA (2014) Five reasons to use bacteria when assessing manufactured nanomaterial environmental hazards and fates. Curr Opin Biotech 27:73-78

12. Rincon-Florez VA, Carvalhais LC, Schenk PM (2013) Culture-independent molecular tools for soil and rhizosphere microbiology. Diversity 5:581-612

13. Gajjar P, Pettee B, Britt DW, Huang W, Johnson WP, Anderson AJ (2009) Antimicrobial activities of commercial nanoparticles against an environmental soil microbe, Pseudomonas putida KT2440. J Biol Eng 3:9

14. Ortega-Calvo JJ, Molina R, Jimenez-Sanchez C, Dobson PJ, Thompson IP (2011) Bacterial tactic response to silver nanoparticles. Environ Microbiol Rep 3:526-534

15. Dimkpa CO, Calder A, Gajjar P, Merugu S, Huang W, Britt DW et al (2011) Interaction of silver nanoparticles with an environmentally beneficial bacterium, Pseudomonas chlororaphis. J Hazard Mater 188:428-435
16. Juan W, Kunhui S, Zhang L, Youbin S (2017) Effects of silver nanoparticles on soil microbial communities and bacterial nitrification in suburban vegetable soils. Pedosphere 27:482-490

17. McGee C, Storey S, Clipson N, Doyle E (2017) Soil microbial community responses to contamination with silver, aluminium oxide and silicon dioxide nanoparticles. Ecotoxicology 26:449-458

18. Kumar N, Shah V, Walker VK (2012) Influence of a nanoparticle mixture on an arctic soil community. Environ Toxicol Chem 31:131-135

19. McGee CF, Storey S, Clipson N, Doyle E (2018) Concentration-dependent responses of soil bacterial, fungal and nitrifying communities to silver nano and micron particles. Environ Sci Pollut. https://doi.org/10.1007/ s11356-018-2087-y

20. Zhang Y, Cong J, Lu H, Li G, Qu Y, Su X, Zhou J, Li D (2014) Community structure and elevational diversity patterns of soil Acidobacteria. J Environ Sci 26:1717-1724

21. Ventura M, Canchaya C, Tauch A, Chandra G, Fitzgerald GF, Chater KF et al (2007) Genomics of Actinobacteria: tracing the evolutionary history of an ancient phylum. Microbiol Mol Biol R 71:495-548

22. Shah V, Collins D, Walker VK, Shah S (2014) The impact of engineered cobalt, iron, nickel and silver nanoparticles on soil bacterial diversity under field conditions. Environ Res Lett 9:024001

23. Schlich K, Hund-Rinke K (2015) Influence of soil properties on the effect of silver nanomaterials on microbial activity in five soils. Environ Pollut 196:321-330

24. Metreveli G, Frombold B, Seitz F, Grün A, Philippe A, Rosenfeldt RR et al (2016) Impact of chemical composition of ecotoxicological test media on the stability and aggregation status of silver nanoparticles. Environ Sci Nano 3:418-433

25. Emmerling C, Schloter M, Hartmann A, Kandeler E (2002) Functional diversity of soil organisms-a review of recent research activities in Germany. J Plant Nutr Soil Sci 165:408-420

26. Menzel M, Bienert R, Bremser W, Girod M, Rolf S, Thünemann A (2013) Certification Report Certified Reference Material BAM-N001 particle size parameters of nano silver. Federal Institute for Materials Research and Testing, Berlin

27. Barns SM, Takala SL, Kuske CR (1999) Wide distribution and diversity of members of the bacterial kingdom Acidobacterium in the environment. Appl Environ Microb 65:1731-1737

28. Muyzer G, De Waal EC, Uitterlinden AG (1993) Profiling of complex microbial populations by denaturing gradient gel electrophoresis analysis of polymerase chain reaction-amplified genes coding for 165 rRNA. Appl Environ Microb 59:695-700

29. Stach JE, Maldonado LA, Ward AC, Goodfellow M, Bull AT (2003) New primers for the class Actinobacteria: application to marine and terrestrial environments. Environ Microbiol 5:828-841

30. Manz W, Amann R, Ludwig W, Vancanneyt M, Schleifer KH (1996) Application of a suite of $16 \mathrm{~S}$ rRNA-specific oligonucleotide probes designed to investigate bacteria of the phylum cytophaga-flavobacter-bacteroides in the natural environment. Microbiology 142:1097-1106

31. De Gregoris BT, Aldred N, Clare AS, Burgess JG (2011) Improvement of phylum- and class-specific primers for real-time PCR quantification of bacterial taxa. J Microbiol Methods 86:351-356

32. Overmann J, Coolen MJ, Tuschak C (1999) Specific detection of different phylogenetic groups of chemocline bacteria based on PCR and denaturing gradient gel electrophoresis of $16 \mathrm{~S}$ rRNA gene fragments. Arch Microbiol 172:83-94

33. Lane DJ (1991) 16S/23S rRNA sequencing. In: Stackebrand E (ed) Nucleic acid techniques in bacterial systematics. Wiley, New York, pp 115-175

34. Fierer N, Bradford MA, Jackson RB (2007) Toward an ecological classification of soil bacteria. Ecology 88:1354-1364

35. Torsvik V, Øvreås L (2002) Microbial diversity and function in soil: from genes to ecosystems. Curr Opin Microbiol 5:240-245

36. Allison SD, Martiny JB (2008) Resistance, resilience, and redundancy in microbial communities. PNAS 105:11512-11519

37. Rotthauwe JH, Witzel KP, Liesack W (1997) The ammonia monooxygenase structural gene amoA as a functional marker: molecular fine-scale analysis of natural ammonia-oxidizing populations. Appl Environ Microbiol 63:4704-4712

38. Li X, Rui J, Xiong J, Li J, He Z, Zhou J et al (2014) Functional potential of soil microbial communities in the maize rhizosphere. PLOS ONE 9:e112609 
39. Ward NL, Challacombe JF, Janssen PH, Henrissat B, Coutinho PM, Wu $M$ et al (2009) Three genomes from the phylum Acidobacteria provide insight into the lifestyles of these microorganisms in soils. Appl Environ Microb 75:2046-2056

40. Philippot L, Andersson SG, Battin TJ, Prosser Jl, Schimel JP, Whitman WB, Hallin S (2010) The ecological coherence of high bacterial taxonomic ranks. Nat Rev Microbiol 8:523

41. Sutton NB, Maphosa F, Morillo JA, Al-Soud WA, Langenhoff AA, Grotenhuis T et al (2013) Impact of long-term diesel contamination on soil microbial community structure. Appl Environ Microb 79:619-630

42. Diez-Ortiz M, Lahive E, George S, Ter Schure A, Van Gestel CA, Jurkschat Ket al (2015) Short-term soil bioassays may not reveal the full toxicity potential for nanomaterials; bioavailability and toxicity of silver ions $\left(\mathrm{AgNO}_{3}\right)$ and silver nanoparticles to earthworm Eisenia fetida in long-term aged soils. Environ Pollut 203:191-198

43. Zhai Y, Hunting ER, Wouterse M, Peijnenburg W, Vijver MG (2016) Silver nanoparticles, ions and shape governing soil microbial functional diversity: nano shapes micro. Front Microbiol 7:1123

44. Grün A-L, Scheid P, Hauröder B, Emmerling C, Manz W (2017) Assessment of the effect of silver nanoparticles on the relevant soil protozoan genus Acanthamoeba. J Plant Nutr Soil Sc 180:602-613

45. Liu J, Hurt RH (2010) lon release kinetics and particle persistence in aqueous nano-silver colloids. Environ Sci Technol 44:2169-2175

46. Li X, Lenhart JJ, Walker HW (2010) Dissolution-accompanied aggregation kinetics of silver nanoparticles. Langmuir 26:16690-16698

47. Wang D, Jaisi DP, Yan J, Jin Y, Zhou D (2015) Transport and retention of polyvinylpyrrolidone-coated silver nanoparticles in natural soils. Vadose Zone J 14:vzj2015.01.0007

48. Klitzke S, Metreveli G, Peters A, Schaumann GE, Lang F (2014) The fate of silver nanoparticles in soil solution-sorption of solutes and aggregation. Sci Total Environ 535:54-60

49. Kim MJ, Ko D, Ko K, Kim D, Lee JY, Woo SM et al (2018) Effects of silvergraphene oxide nanocomposites on soil microbial communities. J Hazard Mater 346:93-102

50. Nies DH (1999) Microbial heavy-metal resistance. Appl Microbiol Biotechnol 51:730-750

51. Wu B, Wang Y, Lee YH, Horst A, Wang Z, Chen DR et al (2010) Comparative eco-toxicities of nano-ZnO particles under aquatic and aerosol exposure modes. Environ Sci Technol 44:1484-1489

52. Sudheer Khan S, Bharath Kumar E, Mukherjee A, Chandrasekaran N (2011) Bacterial tolerance to silver nanoparticles (SNPs): aeromonas punctata isolated from sewage environment. J Basic Microbiol 51:183-190

53. Yang Y, Quensen J, Mathieu J, Wang Q, Wang J, Li M et al (2014) Pyrosequencing reveals higher impact of silver nanoparticles than $\mathrm{Ag}^{+}$ on the microbial community structure of activated sludge. Water Res 48:317-325

54. Schlich K, Klawonn T, Terytze K, Hund-Rinke K (2013) Hazard assessment of a silver nanoparticle in soil applied via sewage sludge. Environ Sci Eur $25: 17$
55. Samarajeewa AD, Velicogna JR, Princz JI, Subasinghe RM, Scroggins RP, Beaudette LA (2017) Effect of silver nano-particles on soil microbial growth, activity and community diversity in a sandy loam soil. Environ Pollut 220:504-513

56. Ma Y, Metch JW, Vejerano EP, Miller IJ, Leon EC, Marr LC et al (2015) Microbial community response of nitrifying sequencing batch reactors to silver, zero-valent iron, titanium dioxide and cerium dioxide nanomaterials. Water Res 68:87-97

57. Voelker C, Oetken M, Oehlmann J (2013) The biological effects and possible modes of action of nanosilver. Rev Environ Contam Toxicol 223:81-106

58. Vasileiadis S, Puglisi E, Trevisan M, Scheckel KG, Langdon KA, McLaughlin $\mathrm{MJ}$ et al (2015) Changes in soil bacterial communities and diversity in response to long-term silver exposure. FEMS Microbiol Ecol 91. https:// doi.org/10.1093/femsec/fiv114

59. Levard C, Hotze EM, Lowry GV, Brown GE Jr (2012) Environmental transformations of silver nanoparticles: impact on stability and toxicity. Environ Sci Technol 46:6900-6914

60. Lowry GV, Gregory KB, Apte SC, Lead JR (2012) Transformations of nanomaterials in the environment. Environ Sci Technol 46:6893-6899

61. Settimio L, McLaughlin MJ, Kirby JK, Langdon KA, Janik L, Smith S (2015) Complexation of silver and dissolved organic matter in soil water extracts. Environ Pollut 199:174-184

62. Cornelis G, Doolette M, Thomas C, McLaughlin MJ, Kirby JK, Beak DG et al (2012) Retention and dissolution of engineered silver nanoparticles in natural soils. Soil Sci Soc Am J 76:891-902

63. Sagee O, Dror I, Berkowitz B (2012) Transport of silver nanoparticles (AgNPs) in soil. Chemosphere 88:670-675

64. Postgate JR (1967) Viability measurements and the survival of microbes under minimum stress. Adv Microb Physiol 1:1-23

65. Ulrich A, Becker R (2006) Soil parent material is a key determinant of the bacterial community structure in arable soils. FEMS Microbiol Ecol 56:430-443

66. Epelde L, Lanzén A, Blanco F, Urich T, Garbisu C (2015) Adaptation of soil microbial community structure and function to chronic metal contamination at an abandoned Pb-Zn mine. FEMS Microbiol Ecol 91:1-11

67. Huang J, Cao C, Yan C, Liu J, Hu Q, Guan W (2017) Impacts of silver nanoparticles on the nutrient removal and functional bacterial community in vertical subsurface flow constructed wetlands. Bioresour Technol 243:1216-1226

68. Das P, Barua S, Sarkar S, Chatterjee SK, Mukherjee S, Goswami L et al (2018) Mechanism of toxicity and transformation of silver nanoparticles: inclusive assessment in earthworm-microbe-soil-plant system. Geoderma 314:73-84

69. Cornelis G, Pang L, Doolette C, Kirby JK, McLaughlin MJ (2013) Transport of silver nanoparticles in saturated columns of natural soils. Sci Total Environ 463:120-130

\section{Submit your manuscript to a SpringerOpen ${ }^{\odot}$ journal and benefit from:}

- Convenient online submission

- Rigorous peer review

- Open access: articles freely available online

- High visibility within the field

Retaining the copyright to your article

Submit your next manuscript at springeropen.com 